\title{
Status of Worker Morale Among College Catalogers
}

\author{
Miss Herrick is assistant librarian, Boston \\ University.
}

$\mathrm{T}$ HERE ARE today two current channels of thought in college library administration concerned with methods of achieving efficiency and lower costs in cataloging procedures. Some writers see this accomplished through a reorganization along departmental lines, resulting in the creation of a division of technical processes. ${ }^{1}$ Lund and Swank advocate a realignment of individual jobs resulting in departmental reorganization as a secondary step. ${ }^{2}$ A further method of determining some of the factors causing the high costs in cataloging is to survey catalogers with an attempt to establish points which are impeding their efficiency and lowering their morale.

Industrial psychologists agree that worker attitudes are of primary importance in any consideration for increasing efficiency or amount of output. It is also known that no single factor-even an important one such as salary-can determine and formulate the attitude of a worker. It is necessary to have a blending of many elements including security, variety and interest in work, a sense of achievement, and opportunity for friendly companionship, to insure the most favorable attitude toward a job.

In a recent study an attempt was made to

${ }^{1}$ Coney, D., "Administration of Technical Processes." In Joeckel, C..B.. ed. Current Issues in Library Administration. Chicago University of Chicago Press, I 939, p. I63-80; "The Technical Services Division in Libraries: A Symposium." College and Research Libraries, 10:46-68, January 1949 .

2 Lund, J. "Cataloging Process in the University Library." College and Research Libraries, 3:21 2-18, June I942'; Swank, R. "The Catalog Department in the Library Organization." Library Quarterly, 18:2432, January 1948 . determine the amount of worker satisfaction among library catalogers. This was done by sending questionnaires to 4I 5 catalogers in various types of libraries throughout the United States. The selection was based on the membership list of the A.L.A. Division of Cataloging and Classification. It was purely an exploratory study of conditions as they exist, with no attempt to validate attitudes, but only to record them as the catalogers themselves stated and evaluated them. The questions ranged from general expressions of opinion on cataloging as a career and as a present job to opinions and practices of the methods and types of work of individual catalogers. Included in the study were I 5 I catalogers in academic institutions. Questionnaires were returned from 92 including 52 from university libraries, 25 from colleges with over I000 students, and I 5 from colleges with less than Iooo students. Table I shows the distribution of the replies from the three types of institutions with age and experience ranges represented.

In addition to recording where they were working, the catalogers were asked to indicate in which type of institution they preferred to work. Only 12 of the group are not satisfied with the type of library in which they are employed. Three university catalogers prefer respectively a small college, a large college, and either type of college but not a university library.

The five catalogers from the large college group expressed preferences as follows: two for a university and a small college, and one for a special library. In the small col- 
Table I

Distribution of Catalogers by Type of Institution, Age Groups and Years of Experience

\begin{tabular}{|c|c|c|c|c|c|c|c|c|}
\hline \multirow{2}{*}{ Library } & \multicolumn{4}{|c|}{ Age Groups by Years } & \multicolumn{4}{|c|}{ Experience by Years } \\
\hline & $2 I-30$ & $3^{I-39}$ & $40-49$ & $50-70$ & $2-5$ & $6-10$ & I I -20 & $2 I-40$ \\
\hline University & 4 & 15 & I8 & I5 & 3 & I4 & 22 & I3 \\
\hline $\begin{array}{l}\text { College } \\
\text { (over I000 students) }\end{array}$ & 3 & 9 & 6 & 7 & 5 & 6 & I I & 3 \\
\hline $\begin{array}{l}\text { College } \\
\text { (under I000 students) }\end{array}$ & 2 & 5 & 5 & 3 & 2 & 5 & 7 & I \\
\hline Totals & 9 & 29 & 29 & 25 & 10 & 25 & 40 & I7 \\
\hline
\end{tabular}

lege group, four preferences were for a large public, large college, university and a medium-sized public library. In each case preferences were backed by previous experience in the type of library chosen.

The catalogers were first asked to check a range of statements designed to indicate their attitudes concerning cataloging as a career and as a present job. For the purpose of comparison with these replies the replies of the total group studied are included.

It can be seen from these percentage figures based on the total persons answering this question that the college groups have somewhat more favorable work attitudes than are represented by the total group.
The variation, however, is not enough to indicate any unusual circumstances. It was also found that the extent of their satisfaction with their work was slightly higher than that found among public library catalogers. Again, however, the difference was small.

The college catalogers were almost equally divided on the reasons by which they chose cataloging as a profession. Fortyseven are in cataloging by choice and 45 by circumstances. Of this latter group, 29 are catalogers because their first jobs included cataloging and they kept on in the field; three took cataloging positions on account of the higher pay offered. The remaining I 3 gave personal reasons such as desire for

Table II

Distribution of Opinions on Cataloging as a Profession and as a Present Job

\begin{tabular}{|c|c|c|c|c|c|c|c|c|}
\hline \multirow{2}{*}{ Opinions } & \multicolumn{4}{|c|}{ Replies of All Groups } & \multicolumn{4}{|c|}{ Replies of Academic Group } \\
\hline & Career & $\begin{array}{l}\text { Percentage } \\
\text { of Group }\end{array}$ & $\begin{array}{c}\text { Present } \\
\text { Job }\end{array}$ & $\begin{array}{c}\text { Percentage } \\
\text { of Group }\end{array}$ & Career & $\begin{array}{l}\text { Percentage } \\
\text { of Group }\end{array}$ & $\begin{array}{l}\text { Present } \\
\text { Job }\end{array}$ & $\begin{array}{l}\text { Percentag } \\
\text { of Group }\end{array}$ \\
\hline Enjoy it & 65 & 32 & 45 & 23 & 30 & 34 & 22 & 25 \\
\hline $\begin{array}{l}\text { Thoroughly } \\
\text { enjoy it }\end{array}$ & 48 & 24 & 43 & 21 & 24 & 27 & 20 & 24 \\
\hline $\begin{array}{l}\text { Enjoy most } \\
\text { aspects }\end{array}$ & 69 & 35 & 88 & 45 & 29 & 33 & 36 & 42 \\
\hline $\begin{array}{l}\text { Dislike some } \\
\text { aspects }\end{array}$ & I 8 & 9 & $2 I$ & I I & 5 & 6 & 8 & 9 \\
\hline $\begin{array}{c}\text { Dislike all } \\
\text { aspects }\end{array}$ & 0 & $\circ$ & $\circ$ & 0 & $\circ$ & $\circ$ & $\circ$ & $\circ$ \\
\hline Totals & 200 & & 197 & & 88 & & 86 & \\
\hline
\end{tabular}


a special community location, a particular library, or because their second job was a cataloging position and they continued in this field.

As a measure of isolating and ranking certain factors relevant to worker satisfaction the catalogers were asked to indicate their opinions on 17 points.

Among the most essential factors in order of rank are proper lighting, interdepartmental cooperation, cordial intrastaff rela-
It was assumed that any factors listed as essential or important in theory would need to be answered as "yes" in practice to represent a satisfactory condition of work. Table $\mathrm{V}$ has been prepared to show as comparison between some of these opinions and conditions as they are present in practice.

Physical working conditions are apparently below the requirements of more than half the catalogers. This lack of adequate lighting facilities, working space and equip-

Table III

Distribution of Opinions on Factors Relevant to Satisfaction in Work

\begin{tabular}{|c|c|c|c|c|}
\hline \multirow{2}{*}{ Factor } & \multicolumn{4}{|c|}{ Number Answering } \\
\hline & Essential & Important & Desirable & Unimportant \\
\hline $\begin{array}{l}\text { Adequate working space } \\
\text { Efficient arrangement of working space } \\
\text { Equable temperature } \\
\text { Proper ventilation } \\
\text { Proper lighting } \\
\text { Sufficient and proper equipment } \\
\text { Opportunity for carrying on of individual } \\
\text { projects } \\
\text { Opportunity for variety in work } \\
\text { Salary } \\
\text { Recognition of professional status of catalogers } \\
\text { by other librarians } \\
\text { Cordial intrastaff relationships } \\
\text { Interdepartmental cooperation } \\
\text { Discriminating assignments of work } \\
\text { Clear demarkation of lines authority } \\
\text { Opportunity for advancement } \\
\text { Faculty status if in a college community } \\
\text { Community location of position }\end{array}$ & $\begin{array}{l}33 \\
26 \\
19 \\
27 \\
58 \\
40 \\
13 \\
17 \\
24 \\
29 \\
29 \\
40 \\
45 \\
26 \\
31 \\
26 \\
15 \\
4\end{array}$ & $\begin{array}{l}35 \\
47 \\
38 \\
42 \\
30 \\
43 \\
17 \\
41 \\
53 \\
39 \\
39 \\
35 \\
38 \\
35 \\
44 \\
27 \\
27\end{array}$ & $\begin{array}{r}23 \\
17 \\
33 \\
22 \\
3 \\
8 \\
\\
47 \\
33 \\
14 \\
\\
21 \\
13 \\
11 \\
24 \\
21 \\
19 \\
40 \\
33\end{array}$ & $\begin{array}{r}0 \\
0 \\
1 \\
0 \\
0 \\
0 \\
\\
10 \\
1 \\
1 \\
1 \\
2 \\
0 \\
0 \\
1 \\
1 \\
0 \\
6 \\
9\end{array}$ \\
\hline
\end{tabular}

tionships, sufficient and proper equipment, adequate working space and clear demarcation of lines of authority. The least important factor is the community location of the job and next to that is the opportunity for the carrying on of individual projects. It is interesting to note that the catalogers rank sixth in importance as an essential their recognition of professional status by other librarians, but faculty status as an essential is twelfth.

They were next asked to rate their own positions on these points as a measure toward determining the adequacy of these factors in practice. Table IV records the replies. ment, plus inequable temperature and poor ventilation, reflects careless planning for a department largely dependent upon these factors for its efficiency.

Two other important factors are insufficiently supplied in on-the-job conditions. These factors-opportunity for advancement and discriminating work assignments -if properly present do much to increase worker morale. Of the total answering this first point 78 per cent checked it as essential or important to have advancement opportunity, but only 29 per cent reported they have this. Seventy-one per cent of this group felt discriminating assignments of work are necessary but only 49 per cent have 
this as a part of their work programs.

The catalogers were asked to indicate preferences for methods and types of work and whether these preferences are met in their jobs. The majority prefer to direct the work of others. They indicated a preference for the use of flexible procedures over standardized routines almost three to one. In general they prefer to work with- to the catalog department. Opinion has been that some time in the reference department is of advantage to both departments and to the library as a whole. Fiftytwo of the college catalogers report that they are scheduled only for work within the catalog department and 38 are not. Thirty catalogers prefer to confine their work within the department, 40 do not, and II

Table IV

Number of Replies on Actual Working Conditions Relevant to Satisfaction in Work

\begin{tabular}{|c|c|c|c|}
\hline & \multicolumn{3}{|c|}{ Total Replies } \\
\hline & Yes & No & $\begin{array}{c}\text { To Some } \\
\text { Extent }\end{array}$ \\
\hline $\begin{array}{l}\text { My work is intellectually stimulating } \\
\text { My work has considerable variety } \\
\text { My work opens up pleasant professional contacts } \\
\text { My work permits individual projects to be developed } \\
\text { My working quarters are adequate } \\
\text { My working quarters are efficiently spaced } \\
\text { My office has proper lighting facilities } \\
\text { My office has equable temperature } \\
\text { My office has proper ventilation } \\
\text { My equipment for work is sufficient and proper } \\
\text { My work is clearly defined and limited } \\
\text { My span of authority is clearly established } \\
\text { My supervisor has assigned work loads with careful } \\
\text { discrimination } \\
\text { My work offers opportunity for advancement } \\
\text { I like the community in which my job is located } \\
\text { I have faculty status (i.e., answer if college or univer- } \\
\text { sity librarian) }\end{array}$ & $\begin{array}{l}18 \\
78 \\
43 \\
27 \\
49 \\
41 \\
41 \\
28 \\
36 \\
44 \\
46 \\
56 \\
34 \\
26 \\
70 \\
36\end{array}$ & $\begin{array}{r}0 \\
1 \\
13 \\
32 \\
25 \\
24 \\
26 \\
38 \\
31 \\
8 \\
9 \\
10 \\
10 \\
35 \\
1\end{array}$ & $\begin{array}{l}13 \\
12 \\
34 \\
29 \\
16 \\
24 \\
22 \\
24 \\
24 \\
35 \\
25 \\
23 \\
25 \\
25 \\
26 \\
20 \\
14\end{array}$ \\
\hline
\end{tabular}

out pressure although 26 reported they like to work under pressure. A slight majority prefer to do both simplified and detailed cataloging rather than only detailed cataloging. They prefer to catalog in various subject fields. In general all these preferences are met on their jobs.

Although the preferences for only detailed or simplified cataloging were not met, the fact that more catalogers do both detailed and simplified cataloging may indicate that no preferences are completely unrealized in practice.

It has usually been accepted in theory that a cataloger's working time is not scheduled to the best advantage if it is confined wholly are indifferent. As may be expected, reference was the major choice among those working outside of the catalog department.

Fifteen clerical routines were selected as representative of many nonprofessional duties carried on in catalog departments. The catalogers were asked to indicate if they did each routine and how they felt toward it. The reports in the general study showed that each routine was done by from 9 to 148 of the catalogers. From the analysis of these totals it was concluded that in general the catalogers doing routines were not dissatisfied on this point. The recorded dislike, which was considerable, reflected more of a theoretical work attitude 
from the catalogers who were not required to do these routines. The amount of recorded indifference was nearly equal to the total liking. This point drew comment from several catalogers. They felt that such a considerable area of indifference by professional librarians on nonprofessional duties indicated an unhealthy inertia. It should be noted, however, in the discussion of these
It might be assumed that within this academic group the university catalogers would be required to perform fewer nonprofessional duties than would the college library catalogers. The distinction between professional and clerical tasks is usually found to be more clearly defined in larger administrative units. The total replies indicating that routines were a part of the work

Table V

Comparison Between Opinions on Theoretical and Actual Conditions of Work

\begin{tabular}{|c|c|c|c|c|}
\hline \multirow[b]{2}{*}{ Factors } & \multicolumn{2}{|c|}{ Opinion } & \multicolumn{2}{|c|}{ On-the-Job Conditions } \\
\hline & $\begin{array}{c}\text { Total } \\
\text { Answers }\end{array}$ & $\begin{array}{l}\text { Number } \\
\text { Reporting } \\
\text { Essential or } \\
\text { Important }\end{array}$ & $\begin{array}{c}\text { Total } \\
\text { Answers }\end{array}$ & $\begin{array}{l}\text { Number } \\
\text { Checking as } \\
\text { Adequate }\end{array}$ \\
\hline $\begin{array}{l}\text { Proper lighting } \\
\text { Opportunity for carrying on individual projects } \\
\text { Opportunity for advancement } \\
\text { Community location of position } \\
\text { Sufficient and proper equipment } \\
\text { Adequate working space } \\
\text { Clear demarcation of lines of authority } \\
\text { Proper ventilation } \\
\text { Efficient arrangement of working space } \\
\text { Discriminating assignments of work } \\
\text { Equable temperature } \\
\text { Opportunity for variety in work } \\
\text { Faculty status }\end{array}$ & $\begin{array}{l}91 \\
87 \\
89 \\
73 \\
91 \\
91 \\
88 \\
91 \\
91 \\
89 \\
91 \\
92 \\
88\end{array}$ & $\begin{array}{l}88 \\
30 \\
70 \\
31 \\
83 \\
68 \\
66 \\
69 \\
73 \\
64 \\
57 \\
58 \\
42\end{array}$ & $\begin{array}{l}89 \\
88 \\
87 \\
91 \\
87 \\
91 \\
89 \\
91 \\
89 \\
69 \\
90 \\
91 \\
86\end{array}$ & $\begin{array}{l}4 \mathbf{1} \\
27 \\
26 \\
70 \\
44 \\
49 \\
56 \\
36 \\
41 \\
34 \\
28 \\
78 \\
36\end{array}$ \\
\hline
\end{tabular}

figures that each cataloger did not check every point, and many catalogers who did not do a routine did indicate an opinion of it. As it has already been mentioned, this opinion often was "dislike" and likewise it was often "indifferent." One cataloger annotated her questionnaire to say that in checking "indifferent" against a number of the routines she was attempting to indicate that if it were necessary to do clerical tasks as a part of her work program, she could do so without active resentment. Table VI shows the total replies received to this question on routines.

On the basis of these replies it is found that the median number of catalogers who are required to do routines is 40 . The median range of opinion on them is: "Like," 2 I ; "dislike," 25 ; "indifferent," I9. program were broken down by types of institutions. From the median number of catalogers in each group reporting that they performed some clerical tasks the following percentage figures were obtained: There are routines required from 28 per cent of the university catalogers; 64 per cent of the large college catalogers; and 66 per cent of the catalogers in small college libraries.

There are Io catalogers in this group who report a thorough satisfaction with both cataloging as a career and as a present job. Three of them are in universities, five in large colleges, and two in small colleges. Eight of this group entered cataloging by choice. Nine of them consider discriminating work assignments and six consider opportunities for advancement as essential or important. 
Six report that their work assignments are made with discrimination. Four have definite opportunities for advancement with three others checking "to some extent." Seven consider faculty status necessary and five report having it. Nine want variety in their work and all Io report it present in their jobs. Six prefer to do detailed cataloging and two do it. Although none pre- and "revision of filing." This latter was also disliked by two other catalogers who were required to do it. All other recorded dislikes were theoretical.

It is apparent from the replies of this group that the highest satisfaction in a job is found, of course, among people who like a certain type of work and find this type required in their positions. There are no out-

Table VI

Replies on the Practice and Desirability of Certain Clerical Routines

\begin{tabular}{|c|c|c|c|c|c|}
\hline \multirow{2}{*}{ Routines } & \multicolumn{5}{|c|}{ Replies } \\
\hline & Do & Do Not Do & Like & Do Not Like & Indifferent \\
\hline Filing cards & 40 & 46 & 37 & 22 & 15 \\
\hline Withdrawing cards & 46 & $4 I$ & 14 & 30 & $3^{2}$ \\
\hline Assigning book numbers & 73 & 20 & 55 & 7 & 19 \\
\hline Pasting books & 8 & 78 & 3 & 43 & 15 \\
\hline Mending books & 6 & 77 & 5 & 44 & 14 \\
\hline Lettering books & 10 & 75 & 18 & 36 & 10 \\
\hline Typing of main card & 53 & 34 & $5^{2}$ & II & 15 \\
\hline Typing of other cards & 20 & 67 & 23 & 37 & 19 \\
\hline Typing of shelf card & 34 & 62 & 18 & 37 & 22 \\
\hline Typing of book cards & 20 & 66 & 19 & 35 & 22 \\
\hline Recording added copies & 47 & 36 & 18 & 20 & 36 \\
\hline Recording serial additions & 40 & 42 & 30 & I 5 & 29 \\
\hline Correction of main entry data & 41 & 28 & 26 & 17 & 28 \\
\hline Revision of copied material & 65 & 18 & 30 & 29 & 20 \\
\hline Revision of filing & 55 & 29 & 39 & 17 & 21 \\
\hline Totals & 558 & 719 & 387 & 394 & $3 \mathrm{I}_{7}$ \\
\hline
\end{tabular}

fer to do only simplified cataloging, four enjoy doing both kinds and eight report this as an on-the-job requirement. There is no expressed preference for subject specialization.

It may be assumed here, for the small group, that as no cataloger preferring to do detailed cataloging has only simplified require, therefore, no cataloger has his preferences completely unrealized. The preference for work outside the cataloging department by four of the group is met in their jobs.

Every clerical routine listed was done by from one to nine of these catalogers. Only two of the group, however, reported disliking two of the routines which they are required to do. The routines required and disliked were "revision of copied material" standing points of difference in working conditions between this small group and the other college catalogers. Each point of preference may be realized in practice to a slightly greater extent than it is in the larger group. They represent about io per cent of the college catalogers.

Although the general level of satisfaction with cataloging is rather high, with 88 of the 92 academic catalogers expressing some measure of enjoyment in cataloging as a career, and 86 enjoying their present jobs, it is obvious that the range of opinion varies from tolerance and general appreciation expressed by the major part of the group, to an expression of a high level of satisfaction by a small section of the group. It is impossible at this time, without comparable data from other branches of librarianship, 
to evaluate the amount of satisfaction in cataloging with reference to any other form of library work. It does seem, however, that it would be of value to explore methods to increase the percentage of those thoroughly satisfied with this work. From the data presented here through the expressions of catalogers themselves, it is apparent that considerable progress needs to be made in increasing the efficiency and comfort of physical working conditions. It is also apparent that more care might be exercised in the appointments of cataloging administrators with a view to increasing the level of staff morale and interest.

A cataloger in one of the eastern women's colleges writes as follows:

"I believe there is something fundamentally wrong in the present situation which makes librarians reluctant to go into cataloging, and often anxious to leave it. I can best describe this situation perhaps, by listing the following factors which I believe ... account in large part for the intangible psychological atmosphere found in this field. I. Isolation from the rest of the library staff. 2. Lack of adequate leadership. All sorts of remedies have been suggested ... from subject specialists to hours for working with the public .... I believe a feasible solution depends on the ability of the head librarian and the head cataloger to bring the catalogers into the main stream of the library's activities."

A university cataloger describes a job situation which seems to reflect inefficient administrative planning and possibly poor job classification: "Order and cataloging were combined as 'Technical Processes' ... I am still called 'Head Cataloger' ... but actually I have no authority whatever. .."

Another university cataloger refers indirectly to a type of situation that might be influential in forming work attitudes: "In my own mind I have a study to be incorporated in an article on the social status of library staff members in a college community as compared with the teaching faculty."

A former cataloger of distinction, now a college librarian, writes that he feels the catalogers' expressions of preferences for administrative work do not reflect merely a desire to get away from requirements of certain mechanical routines. He believes that the over-all rigidity of work patterns of cataloging departments in the past has tended to destroy or send elsewhere the initiative so badly needed if real progress and constructive thinking in this field are to be achieved.

\section{Resignations in Two University Libraries}

\section{(Continued from page 32)}

for library administrators. The characteristics of the resigners should be extensively analyzed. More information is needed in regard to the best methods for controlling turnover in libraries. Cost analyses of turnover should be made in order to determine whether librarians are justified in making efforts to control turnover. A more narrow definition of the factors influencing the rate of turnover should be made.

Knowledge of the turnover situation is an important step toward gaining control of the personnel problem in libraries. It is a challenge to scholars to make contributions in such a vital, yet relatively unexplored area. 